\title{
BMJ Open Heat stress, hydration and uric acid: a cross-sectional study in workers of three occupations in a hotspot of Mesoamerican nephropathy in Nicaragua
}

\author{
Catharina Wesseling, ${ }^{1}$ Aurora Aragón, ${ }^{2}$ Marvin González, ${ }^{2,3}$ Ilana Weiss, ${ }^{4}$ \\ Jason Glaser, ${ }^{3,4}$ Christopher J Rivard, ${ }^{5}$ Carlos Roncal-Jiménez, ${ }^{5}$ \\ Ricardo Correa-Rotter, ${ }^{6}$ Richard J Johnson ${ }^{5}$
}

To cite: Wesseling $C$, Aragón A, González M, et al. Heat stress, hydration and uric acid: a cross-sectional study in workers of three occupations in a hotspot of Mesoamerican nephropathy in Nicaragua. BMJ Open 2016;6:e011034. doi:10.1136/bmjopen-2016011034

- Prepublication history and additional material is available. To view please visit the journal (http://dx.doi.org/ 10.1136/bmjopen-2016011034).

Received 3 January 2016 Revised 2 November 2016 Accepted 17 November 2016

CrossMark

For numbered affiliations see end of article.

Correspondence to Dr Catharina Wesseling; inekewesseling@gmail.com

\section{ABSTRACT}

Objectives: To study Mesoamerican nephropathy (MeN) and its risk factors in three hot occupations.

Design: Cross-sectional.

Setting: Chinandega and León municipalities, a MeN hotspot on the Nicaraguan Pacific coast, JanuaryFebruary 2013.

Participants: 194 male workers aged 17-39 years: 86 sugarcane cutters, 56 construction workers, 52 smallscale farmers.

Outcome measures: (1) Differences between the three occupational groups in prevalences/levels of socioeconomic, occupational, lifestyle and health risk factors for chronic kidney disease (CKD) and in biomarkers of kidney function and hydration; (2) differences in prevalences/levels of CKD risk factors between workers with reduced estimated glomerular filtration rate (eGFR $\mathrm{CKD}_{\text {CPI }}<80 \mathrm{~mL} / \mathrm{min} / 1.73 \mathrm{~m}^{2}$ ) and workers with normal kidney function (eGFR $\mathrm{CKD}_{\text {-EPI }}$ $\geq 80 \mathrm{~mL} / \mathrm{min} / 1.73 \mathrm{~m}^{2}$ ).

Results: Sugarcane cutters were more exposed to heat and consumed more fluid on workdays and had less obesity, lower blood sugar, lower blood pressure and a better lipid profile. Reduced eGFR occurred in $16 \%, 9 \%$ and $2 \%$ of sugarcane cutters, construction workers and farmers, respectively (trend cane > construction $>$ farming, $\mathrm{p}=0.003$ ). Significant trends (cane > construction > farming) were also observed for high serum urea nitrogen (blood urea nitrogen (BUN) $>20 \mathrm{mg} / \mathrm{dL}$ ), high serum creatinine (SCr $>1.2 \mathrm{mg} / \mathrm{dL})$, low urinary $\mathrm{pH}(\leq 5.5)$ and high BUN/SCr ratio $(>20)$ but not for high urinary specific gravity $(\geq 1.030)$. Sugarcane cutters also more often had proteinuria and blood and leucocytes in the urine. Workers with $\mathrm{eGFR}<80 \mathrm{~mL} / \mathrm{min} / 1.73 \mathrm{~m}^{2}$ reported a higher intake of water and lower intake of sugary beverages. Serum uric acid levels related strongly and inversely to eGFR levels (adj $\beta-10.4 \mathrm{~mL} / \mathrm{min} / 1.73 \mathrm{~m}^{2}$, $95 \% \mathrm{Cl}-12.2$ to $-8.5, \mathrm{p}<0.001)$. No associations were observed for other metabolic risk factors, pesticides, non-steroidal anti-inflammatory drugs or alcohol. Among cane cutters, consumption of
Strengths and limitations of this study

- The study provides a detailed description of exposures to potential risk factors for Mesoamerican nephropathy (MeN) among workers in three occupations of special interest: subsistence farmers, construction workers and sugarcane cutters.

- The study established the prevalence of kidney dysfunction and dehydration among workers in these three distinct occupations at risk for MeN.

- The cross-sectional design limits causal interpretations about associations between the potential risk factors and the markers of kidney function, but the study provides clues for aetiology and possible pathways of kidney injury.

- Most exposures to risk factors are self-reported, but much attention was paid to the quality of the questionnaires.

electrolyte hydration solution appeared preventive (adj $\beta 8.1 \mathrm{~mL} / \mathrm{min} / 1.73 \mathrm{~m}^{2}, \mathrm{p}=0.09$ ).

Conclusions: Heat stress, dehydration and kidney dysfunction were most common among sugarcane cutters. Kidney dysfunction also occurred to a lesser extent among construction workers, but hardly at all among small-scale farmers. High serum uric acid was associated with reduced kidney function.

\section{INTRODUCTION}

Mesoamerican nephropathy $(\mathrm{MeN})$, an epidemic of chronic kidney disease (CKD), is a chronic tubulointerstitial disease unrelated to traditional CKD risk factors, affecting predominantly young male workers in Pacific coastal communities of Central America and possibly southern Mexico. ${ }^{1-4}$ Several tens of thousands of people have died of this 
disease. ${ }^{3}$ Although $\mathrm{MeN}$ is often described as an epidemic of agricultural workers, ${ }^{1}{ }^{5-8}$ in Central America sugarcane workers are clearly the most affected population. ${ }^{1910}$

A consistent risk factor for MeN appears to be heavy manual labour in extreme heat. ${ }^{1}$ Manual sugarcane cutters exert substantial amounts of energy, often in environmental temperatures over $35^{\circ} \mathrm{C}$ and high humidity. ${ }^{11-13}$ Besides heat stress, some sugarcane workers are also exposed to pesticides, either at sugarcane plantations or while labouring in other crops. ${ }^{11}{ }^{14}$ Consumption of non-steroidal anti-inflammatory drugs (NSAIDs) to manage muscle pain is common. ${ }^{15}$ Exposure to heavy metals may occur through contaminated pesticide formulations and fertilisers, as has been shown in Sri Lanka, ${ }^{16}$ contaminated drinking water, ${ }^{17}$ or even during burning of the cane. ${ }^{18}$ Overall, exposure of sugarcane workers to different potential CKD risk factors has not been described in detail.

A leading hypothesis is that recurrent dehydration, possibly in combination with exposure to other agents (eg, NSAIDs, heavy metals, agrochemicals, high fructose intake) may be a driving factor. ${ }^{1}{ }^{4}$ Animal experiments have shown that dehydration and hyperosmolarity may induce tubular injury via activation of the polyolfructokinase pathway in the kidney. ${ }^{19}$ Recently, a mechanism of hyperuricaemia and cyclical uricosuria associated with volume loss and dehydration has also been proposed. ${ }^{2021}$

Studies suggest that MeN may also occur among miners and construction workers, ${ }^{5}{ }^{22}$ cotton workers ${ }^{23}$ and subsistence farmers. ${ }^{6}$ However, these cross-sectional data mostly consider current occupation and are therefore not conclusive. Cane cutting is seasonal and many sugarcane workers are also subsistence farmers or work in construction. Contrary to contracted workers, independent small-scale farmers have control over their work hours and are able to avoid the hottest temperatures. Prevalence studies have been recommended to assess exposure to CKD risk factors and kidney dysfunction in different occupations. ${ }^{1}$

The aim of this study was to compare the prevalence of a range of potential CKD risk factors among sugarcane cutters, construction workers and small-scale farmers labouring in the same hot environment, along with biomarkers of hydration and kidney function. We hypothesise that sugarcane cutters experience more heat stress, more dehydration and more signs of kidney dysfunction than small-scale farmers, with construction workers somewhere in between.

\section{METHODS}

\section{Study population and recruitment}

This is a cross-sectional study. We recruited 194 male workers aged 17-39 years, all living in the municipalities of Chinandega and León in the Pacific region of Nicaragua, a major epicentre for the MeN epidemic. Of these, 86 were sugarcane cutters, 56 construction workers and 52 small-scale farmers. Cane cutters from several sugarcane villages were recruited with the help of community leaders; a trade union assisted in recruiting construction workers employed by private companies at three construction sites; and a rural farmer association helped to recruit associated farmers dedicated full time to the cultivation of subsistence crops. The response rate was $86 \%$ among cane cutters and there were no refusals among construction workers and farmers.

The study was approved by the Ethical Review Board of UNAN-León, Nicaragua. All participants provided written informed consent.

\section{Data collection}

Data were collected for sugarcane cutters during January 2013, 2 months after the sugarcane harvest started, and during February 2013 for construction workers and farmers under similar climatic conditions. In each of the sugarcane and farming villages a wellknown public place was selected as the data collection station; construction workers were evaluated at their work site. Data collection started between 05:30 and 06:00 hours on the morning after a workday and blood and urine samples were collected after overnight fasting.

\section{Medical measurements and biological samples}

Blood pressure was measured with a calibrated digital sphygmomanometer with the participant seated after resting for $10 \mathrm{~min}$. Weight was measured with a calibrated digital flat mobile scale and height with a foldable stadiometer. Certified technicians collected blood samples in vacuum tubes for centrifugation and serum separation and in a tube with anticoagulant for blood cell count. Samples without coagulant were centrifuged on the spot at $3500 \mathrm{rpm}$ for $10 \mathrm{~min}$ at room temperature. All samples were placed on ice and transported the same day to the laboratory at the Research Center on Health, Work and Environment (CISTA) at UNAN-León where haematocrit and haemoglobin were determined with a Mindray 2300 haematology analyser and the serum samples were frozen at $-80^{\circ} \mathrm{C}$. After finalising all data collection, serum samples were transported to the National Diagnostic and Reference Center of the Ministry of Health (CNDR-MINSA) of Nicaragua, which takes part in an international interlaboratory quality control programme. Samples were analysed with Cobas Integra 400 , an automated equipment which uses a photometric test to determine levels of serum glucose, lipid profile, serum uric acid (S-UA) and blood urea nitrogen (BUN) and a Jaffe compensated method for quantification of serum creatinine $(\mathrm{SCr})$. $\mathrm{SCr}$ was calibrated against IDMS-traceable creatinine. Blind spiked and duplicate blood samples from each tenth participant were in $95 \%$ within 1 SD. A urinalysis dipstick was performed on a spot morning sample using a Bayer Clinitek 50 Urine Chemistry Analyser with Multistix 10SG reagent strips (Siemens Diagnostics, USA) with 
semi-quantitative measurements of protein $(\geq 30$ $<300 \mathrm{mg} / \mathrm{dL}$ and $\geq 300 \mathrm{mg} / \mathrm{dL}$, glucose (positive at $\geq 100 \mathrm{mg} / \mathrm{dL}$ ), urinary specific gravity (USG) (1.0001.030), $\mathrm{pH}$ (5.0-8.5), blood (+ to +++), nitrite (positive), leucocyte esterase ( + to +++$)$, bilirubin (+ to +++$)$, ketone $(\geq 5 \mathrm{mg} / \mathrm{dL})$ and urobilinogen $(\geq 2$ Ehrlich units).

\section{Questionnaires}

Questionnaires were applied by trained interviewers with courses on bioethics and good clinical practices. A questionnaire on work and health obtained data on demographics and employment (age, education, drinking water source, income, type of contract, sub-employment, social security), lifestyle (smoking, alcohol, drugs, fluid intake on non-working days), health (medically diagnosed diseases, nephrotoxic medications), work history (industry, job titles, job duration, crops, pesticides) and occupational heat stress determinants (shift duration, breaks, shadow, work speed, heavy loads; in addition, for sugarcane workers, incentives to cut more cane and hours between cane burning and entering the field). This questionnaire was developed based on versions used in previous studies in the region. ${ }^{5} 2324$

A second questionnaire, developed at the National Institute of Public Health in Mexico, obtained data on the types and amounts of fluids and food items consumed during the day (always a workday) before the interview. The amount of fructose contained in the food and drinking items was estimated based on a fructose calculation list of the Mexican questionnaire ${ }^{25}$ and the USDA National Nutrient Database for Standard Reference for items not included in the Mexican questionnaire. ${ }^{26}$

\section{Statistical analysis}

Data were analysed with SPSS Statistics 20. Glomerular filtration rate estimated by the CKD-EPI equation $\left(\right.$ eGFR $\left._{\text {CKD-EPI }}\right)$ was the main outcome measure, categorised into $<80 \mathrm{~mL} / \mathrm{min} / 1.73 \mathrm{~m}^{2}$ and $\geq 80 \mathrm{~mL} / \mathrm{min} /$ $1.73 \mathrm{~m}^{2}$. This cut-off point was chosen instead of the traditional $<60$ because too few workers had estimated glomerular filtration rate $(\mathrm{eGFR})<60$. Prevalences of high BUN $(>20 \mathrm{mg} / \mathrm{dL})$, high $\mathrm{SCr}(>1.2 \mathrm{mg} / \mathrm{dL})$, high S-UA $(>7.2 \mathrm{mg} / \mathrm{dL})$ and protein $>30 \mathrm{mg} / \mathrm{dL}$, blood, nitrites or leucocytes in urine were secondary measures of kidney dysfunction. Prevalences of high USG $(\geq 1.030)$, low urinary $\mathrm{pH}(\leq 5.5)$ and high $\mathrm{BUN} / \mathrm{SCr}$ ratio $(>20)$ were used as indicators of dehydration.

Self-reported social and work history items, diseases and medications, and heat stress exposure variables were dichotomised. A category of high tobacco consumption was created with subjects in the upper quartile of ever smokers ( $\geq 3$ pack-years) and a category of high alcohol consumption composed of subjects in the upper tertiles of lifetime alcohol consumption $(\geq 80000 \mathrm{~g})$ or average weekly consumption $(\geq 125 \mathrm{~g})$. Total fluid intake was defined as drinking water plus sugary drinks (natural fruit refreshments, sodas, coffee, tea and electrolyte solution) and reported as litres of total liquids consumed the previous (work) day and for comparison also for a typical non-work day, with subcategories into water only and sugary drinks. Total fructose intake was estimated from all food and fluids consumed including chewed cane and stratified into fructose from food sources and added sugars. Fructose variables were categorised into quartiles. The cut-off for body mass index was set at $\geq 25 \mathrm{~kg} / \mathrm{m}^{2}$. Hypertension was defined as systolic blood pressure $\geq 140 \mathrm{~mm} \mathrm{Hg}$ and/or diastolic blood pressure $\geq 90 \mathrm{~mm} \mathrm{Hg}$, or a self-reported medical history of hypertension. Diabetes was defined as serum glucose $\geq 125 \mathrm{mg} / \mathrm{dL}$ in the fasting serum sample or a selfreported medical history of diabetes. Use of nephrotoxic medications was recorded if taken at least three times per week for more than 3 months in the case of NSAIDs and other analgesics, or administered for at least a week in the case of nephrotoxic antibiotics, during the last year. Blood and urine biochemical parameters were explored as continuous variables or defined as normal versus abnormal using standard clinical cut-off values.

Differences between occupations were assessed with ANOVA and Kruskal-Wallis tests for normally and not normally distributed continuous variables, respectively, and Pearson $\chi^{2}$ test for categorical variables or Fisher's exact test when the $\chi^{2}$ test was not applicable. Post hoc tests were performed with Tukey's HSD test for continuous results and post-hoc $\chi^{2}$ as described by Franke et $a l^{27}$ With occupation as the main proxy for heat stress, we assessed trends for sugarcane cutters > construction workers $>$ farmers for prevalences of markers of kidney dysfunction and dehydration over the ordered occupational groups with the gamma statistic.

Differences in the distribution of risk factors between subjects with reduced and normal kidney function were explored for all occupations combined $(n=194)$ and restricted to sugarcane cutters $(n=86)$, with Whitney U-tests for continuous variables and $\chi^{2}$ tests or Fisher's exact test for categorical variables. Exact $p$ values are reported and $p$ values $\leq 0.05$ were considered statistically significant. Multivariate linear regression models were constructed for all workers and restricted to sugarcane cutters, with factors that were different between subjects with reduced and normal kidney function at $\mathrm{p}<0.10$. Residuals from the regressions were checked to assess the fit of the models.

\section{RESULTS \\ Potential risk factors for CKD/MeN among the three occupations \\ Socioeconomic and health-related CKD risk factors}

Socioeconomic CKD risk indicators were unfavourable for all workers, but somewhat less for construction workers (table 1A). Farmers had the lowest income and sugarcane cutters were significantly less educated with an average of 4 years of elementary schooling. With 
Table 1 Socioeconomic and health indicators relevant for chronic kidney disease/Mesoamerican nephropathy risk among workers in three occupations, municipalities of Chinandega and León, Nicaragua, 2013

\begin{tabular}{|c|c|c|c|c|}
\hline & $\begin{array}{l}\text { Sugarcane } \\
(\mathrm{N}=86)\end{array}$ & $\begin{array}{l}\text { Construction } \\
(\mathrm{N}=56)\end{array}$ & $\begin{array}{l}\text { Farming } \\
(\mathrm{N}=52)\end{array}$ & $\begin{array}{l}\text { p Value* differences } \\
\text { between groups }\end{array}$ \\
\hline \multicolumn{5}{|l|}{ (A) Demographics, employment and social indicators } \\
\hline Age (years) & $25.6 \pm 5.5$ & $27.3 \pm 6.0$ & $25.2 \pm 5.1$ & 0.11 \\
\hline Education (years) & $3.9 \pm 3.0 \dagger$ & $7.8 \pm 3.6$ & $8.0 \pm 4.1$ & $<0.001$ \\
\hline Drinking water from well, \% & 84.9† & 12.5 & 13.5 & $<0.001$ \\
\hline Temporary contract, \% & $93.0 \dagger$ & $75.0 \dagger$ & $21.1 \dagger$ & $<0.001$ \\
\hline Without work $\geq 4$ months/year, $\%$ & 20.9 & 17.9 & $34.6 \dagger$ & 0.089 \\
\hline No current social security, \% & 15.1 & 8.9 & $92.3 \dagger$ & $<0.001$ \\
\hline $\begin{array}{l}\text { Monthly household income per person in family } \\
\text { ( } 25 \text { córdobas }=1 \text { US } \$ \text { ) }\end{array}$ & $1808 \pm 1156 \dagger$ & $2267 \pm 1124 \dagger$ & $1343 \pm 1059 \dagger$ & $<0.001$ \\
\hline \multicolumn{5}{|l|}{ (B) Lifestyle, medical history and health indicators } \\
\hline High tobacco consumption, \% & $10.5 \dagger$ & 26.8 & 23.1 & 0.031 \\
\hline High alcohol consumption, \% & 18.6 & 28.6 & 32.7 & 0.145 \\
\hline Non-steroidal anti-inflammatory drugs $\geq 3$ months, $\%$ & 5.8 & 7.1 & 7.7 & 0.901 \\
\hline Nephrotoxic antibiotics, \% & 1.2 & 1.8 & 0.0 & 0.648 \\
\hline History of kidney stones, \% & 1.2 & 5.4 & 1.9 & 0.287 \\
\hline History of urinary tract infections, \% & $23.3 \ddagger$ & 33.9 & $42.3 \ddagger$ & 0.058 \\
\hline Not feeling in good health, $\%$ & $10.5 \S$ & $37.5 \S$ & 17.5 & $<0.001$ \\
\hline Body mass index $\geq 25 \mathrm{~kg} / \mathrm{m}^{2}, \%$ & $17.4 \S$ & $58.9 \S$ & 40.4 & $<0.001$ \\
\hline Blood pressure >140/90, \% & $5.8 \dagger$ & 17.9 & 26.9 & 0.003 \\
\hline Heart rate (beats/min) & $62 \pm 12 \dagger$ & $73 \pm 14$ & $72 \pm 13$ & $<0.001$ \\
\hline Blood glucose (mg/dL) & $89 \pm 11$ & $90 \pm 14$ & $90 \pm 12$ & 0.874 \\
\hline Triglycerides (mg/dL) & $120 \pm 67 \dagger$ & $168 \pm 108$ & $177 \pm 124$ & $<0.001$ \\
\hline Cholesterol (mg/dL) & $170 \pm 36 \S$ & $188 \pm 41 \S$ & $178 \pm 44$ & 0.032 \\
\hline HDL cholesterol (mg/dL) & $48 \pm 12 \dagger$ & $42 \pm 10$ & $38 \pm 8$ & $<0.001$ \\
\hline LDL cholesterol (mg/dL) & $93 \pm 28$ & $101 \pm 33$ & $91 \pm 32$ & 0.120 \\
\hline VLDL cholesterol (mg/dL) & $24 \pm 13 \dagger$ & $34 \pm 22$ & $35 \pm 25$ & $<0.001$ \\
\hline Haematocrit (\%)ף & $46.8 \pm 5.9$ & $48.5 \pm 4.8$ & $50.8 \pm 4.0 \dagger$ & $<0.001$ \\
\hline Haemoglobin $(\mathrm{g} / \mathrm{dL}) \uparrow$ & $13.4 \pm 1.6 \dagger$ & $14.8 \pm 1.5$ & $15.4 \pm 1.3$ & $<0.001$ \\
\hline Haemoglobin <13 g/dL, \%ף & $35.8 \dagger$ & 8.9 & 3.8 & $<0.001$ \\
\hline White cell counts $/ \mu \mathrm{L} \eta,{ }^{* *}$ & $7184 \pm 2048$ & $7307 \pm 1656$ & $7580 \pm 1882$ & 0.503 \\
\hline \% neutrophils |, ,* & $38.6 \pm 10.6$ & $38.6 \pm 8.8$ & $36.5 \pm 9.0$ & 0.421 \\
\hline \% lymphocytesף, ${ }^{\star *}$ & $21.2 \pm 6.6 \dagger$ & $18.5 \pm 4.9 \dagger$ & $14.5 \pm 4.7 \dagger$ & $<0.001$ \\
\hline$\%$ other cells $]^{* \star}$ & $40.2 \pm 10.0$ & $43.0 \pm 8.2$ & $49.1 \pm 10.6 \dagger$ & $<0.001$ \\
\hline Erythrocytes $\times 10^{6} / \mu \mathrm{L}$. & $4.87 \pm 0.59 \dagger$ & $5.27 \pm 0.47 \dagger$ & $5.53 \pm 0.50 \dagger$ & $<0.001$ \\
\hline Platelets $\times 10^{3} / \mu \mathrm{L}$ & $299.4 \pm 76.7$ & $315.6 \pm 67.7$ & $292.8 \pm 62.8$ & 0.218 \\
\hline
\end{tabular}

Values are mean \pm SD unless indicated otherwise.

* $p$ Value for differences between groups: ANOVA for normally distributed continuous variables, Kruskal-Wallis for not normally distributed continuous variables, $\chi^{2}$ test for categorical variables.

†Significantly different from the other two categories in post hoc tests.

$\ddagger$ Significant difference only between sugarcane cutters and farmers.

$\S S$ ignificant difference only between sugarcane cutters and construction workers.

\5 missing data for sugarcane workers due to technical error.

${ }^{* *}$ Exclusion of one farmer with outlier for white blood cell count (WBC count $\left.=17500 / \mu \mathrm{L}\right)$.

HDL, high density lipoprotein; LDL, low density lipoprotein; VLDL, very low density lipoprotein.

regard to lifestyle and medical factors (table 1B), sugarcane cutters had lower prevalences of high tobacco and alcohol consumption. There were no major differences in the use of nephrotoxic drugs between the groups. None of the workers had been previously diagnosed with diabetes and only five had hyperglycaemia $>125 \mathrm{mg} / \mathrm{dL} \quad(2$ sugarcane cutters, 2 construction workers and 1 farmer). Sugarcane cutters showed less obesity, better lipid profiles, lower heart rates and lower blood pressure but more anaemia (36\% with haemoglobin $<13 \mathrm{~g} / \mathrm{dL}$ ). There were no differences in total leucocyte count between occupations.
Occupational heat exposure, fluid and fructose intake and pesticides

On average, construction workers had an effective work time of 8 hours and farmers had the shortest with 5 hours, whereas sugarcane workers actively cut cane for 6.5 hours per day (table 2A). A higher proportion of sugarcane workers perceived a very rapid work pace and had to take rest breaks in the absence of shade; $83 \%$ received incentives for cutting more cane and almost half started harvesting within 12 hours of burning the cane. Sugarcane cutters more often reported weight loss related to the current job (over the last 2 months) and 
Table 2 Occupational heat stress, fluid and fructose intake and pesticide exposure indicators among workers in three occupations, municipalities of Chinandega and León, Nicaragua, 2013

\begin{tabular}{|c|c|c|c|c|}
\hline & $\begin{array}{l}\text { Sugarcane } \\
(\mathrm{N}=86)\end{array}$ & $\begin{array}{l}\text { Construction } \\
(\mathrm{N}=56)\end{array}$ & $\begin{array}{l}\text { Farming } \\
(\mathrm{N}=52)\end{array}$ & p Value ${ }^{*}$ \\
\hline \multicolumn{5}{|l|}{ (A) Current occupational heat stress } \\
\hline Effective work hours per day (work hours minus breaks) & $6.5 \pm 1.2 \dagger$ & $8.1 \pm 0.7 \dagger$ & $5.3 \pm 2.0 \dagger$ & $<0.001$ \\
\hline Very rapid work pace, \% & $74.4 \dagger$ & 53.6 & 40.4 & $<0.001$ \\
\hline No shade during breaks, \% & $20.9 \ddagger$ & $1.8 \ddagger$ & 11.5 & 0.004 \\
\hline Lifting weights >50 lbs, \% & $18.6 \dagger$ & 66.1 & 65.4 & $<0.001$ \\
\hline Awkward work postures, \% & 58.1 & 76.8 & 69.2 & 0.063 \\
\hline Incentives to cut more cane, \% & 82.6 & - & - & - \\
\hline Hours post-burning at field entrance & $11.7 \pm 6.2$ & - & - & - \\
\hline Self-reported weight loss on the current job (last 2 months), \% & $77.9 \dagger$ & 39.3 & 36.5 & $<0.001$ \\
\hline Fainted at work, \% & 5.8 & 0 & 1.9 & 0.126 \\
\hline Dysuria ('chistata'), \% & 43.0 & 48.2 & 44.2 & 0.827 \\
\hline \multicolumn{5}{|l|}{$\begin{array}{l}\text { (B) Fluid and fructose intake } \\
\text { Fluid intake previous dav (workdav) }\end{array}$} \\
\hline Total fluid (L) & $6.2 \pm 4.1 \dagger$ & $4.4 \pm 2.1$ & $4.0 \pm 2.7$ & 0.003 \\
\hline Water & $4.4 \pm 3.9 \dagger$ & $2.9 \pm 2.1$ & $2.8 \pm 2.4$ & 0.002 \\
\hline Sugary drinks without electrolyte hydration solution & $1.8 \pm 1.8$ & $1.5 \pm 0.9$ & $1.2 \pm 0.8$ & 0.208 \\
\hline Electrolyte solution $(\mathrm{N}=31)$ & $1.2 \pm 1.1$ & - & - & - \\
\hline Lowest quartile total fluid ( $\leq 2.5 \mathrm{~L}$ ), \% & 18.6 & 19.6 & $40.4 \dagger$ & 0.009 \\
\hline Highest quartile total fluid $(\geq 7.0 \mathrm{~L}), \%$ & $40.7 \dagger$ & 8.9 & 13.5 & $<0.001$ \\
\hline \multicolumn{5}{|l|}{ (C) Fluid intake on typical non-work day } \\
\hline Total fluid (L) & $4.2 \pm 2.3$ & $3.8 \pm 1.7$ & $4.1 \pm 2.2$ & 0.503 \\
\hline Water & $3.0 \pm 2.0$ & $2.2 \pm 1.3$ & $2.7 \pm 2.0$ & 0.053 \\
\hline Sugary drinks & $1.2 \pm 1.1$ & $1.6 \pm 1.1$ & $1.4 \pm 1.9$ & 0.117 \\
\hline \multicolumn{5}{|l|}{ (D) Fructose intake previous day (workday) } \\
\hline Total fructose intake $(\mathrm{g})$ & $103.1 \pm 72.1 \dagger$ & $80.1 \pm 46.1$ & $70.9 \pm 36.8$ & 0.008 \\
\hline From food sources & $8.4 \pm 10.7 \dagger$ & $15.9 \pm 16.6$ & $17.4 \pm 16.7$ & $<0.001$ \\
\hline From added sugar & $94.7 \pm 70.5 \dagger$ & $64.2 \pm 38.1$ & $53.2 \pm 30.7$ & $<0.001$ \\
\hline During work hours & $58.6 \pm 44.7 \dagger$ & $28.6 \pm 21.4$ & $26.1 \pm 16.5$ & $<0.001$ \\
\hline Sugary drinks ('frescos', sodas, coffee) & $22.5 \pm 15.7$ & $28.6 \pm 21.4$ & $26.1 \pm 16.3$ & 0.108 \\
\hline Sugarcane chewing $(\mathrm{N}=53)$ & $35.0 \pm 18.5$ & - & - & - \\
\hline Electrolyte solution $(\mathrm{N}=31)$ & $40.3 \pm 35.2$ & - & - & - \\
\hline Outside (before and after) work hours & $36.1 \pm 39.3$ & $35.6 \pm 31.4$ & $27.1 \pm 25.9$ & 0.350 \\
\hline Highest quartile total fructose intake ( $>107 \mathrm{~g}), \%$ & $40.7 \dagger$ & 19.6 & 15.7 & 0.002 \\
\hline \multicolumn{5}{|l|}{ (E) Work and pesticide use history } \\
\hline Cumulative time on current job (months) & $77 \pm 60$ & $68 \pm 80$ & $116 \pm 67 \dagger$ & 0.001 \\
\hline Ever sugarcane work, \% & $100.0 \dagger$ & 3.6 & 3.8 & $<0.001$ \\
\hline Ever plantation (other than sugarcane), \% & 24.4 & $5.4 \dagger$ & 21.2 & 0.012 \\
\hline Ever work in small-scale agricultural (\%) & $61.6 \dagger$ & $25.0 \dagger$ & $100.0 \dagger$ & $<0.001$ \\
\hline Ever construction work, \% & 5.8 & $100.0 \dagger$ & 11.5 & $<0.001$ \\
\hline Ever any pesticide use, \% & $46.5 \dagger$ & $10.7 \dagger$ & $71.2 \dagger$ & $<0.001$ \\
\hline Glyphosate, \% & $19.8 \dagger$ & 0.0 & 3.8 & $<0.001$ \\
\hline $2,4-D, \%$ & $23.3 \dagger$ & $0.0 \dagger$ & $9.6 \dagger$ & $<0.001$ \\
\hline Paraquat, \% & 9.3 & 3.6 & $25.0 \dagger$ & 0.002 \\
\hline Chlorpyrifos, \% & 0.0 & 0.0 & $23.1 \dagger$ & $<0.001$ \\
\hline Cypermethrin, \% & $18.6 \dagger$ & $3.6 \dagger$ & $42.6 \dagger$ & $<0.001$ \\
\hline
\end{tabular}

Values are mean \pm SD unless indicated otherwise.

* $p$ Value for differences between groups: ANOVA for normally distributed continuous variables, Kruskal-Wallis for not normally distributed continuous variables, $\chi^{2}$ test for categorical variables.

†Significantly different from the other two categories in post hoc tests.

$\ddagger$ Significant difference only between sugarcane cutters and construction workers.

fainting on the job (6\% compared with $2 \%$ of farmers and no construction workers). Dysuria ('chistata'), a common symptom in MeN affected areas thought to be related to dehydration, ${ }^{15}{ }^{24}$ was not different between the three groups.
With regard to fluid intake (table 2B), sugarcane cutters reported on average $6.2 \mathrm{~L}$ of total fluid intake the previous (work) day, $70 \%(4.4 \mathrm{~L})$ as water and almost $30 \%(1.8 \mathrm{~L})$ as sugary drinks. This was higher than for construction workers and farmers. Intake of 
water and sugary beverages were not correlated $\left(r_{p}=0.01\right)$. In contrast, there was no difference between the three groups for total fluid, water and sugary drinks intake on non-work days.

Fructose intake during the previous day was highest for sugarcane cutters and $41 \%$ of sugarcane cutters belonged to the category of highest quartile of consumption of total fructose $(>107 \mathrm{~g})$ (table 2B). Fructose intake from food was low among sugarcane cutters and most came from added sugars during work hours, specifically from sweetened beverages, electrolyte hydration solution (one-third of cutters) and cane chewing (about two-thirds). Fructose intake outside work hours was not different between the groups.

With regard to pesticide exposures (table 2C), farmers used pesticides most frequently $(71 \%)$ compared with almost half of sugarcane cutters and only $11 \%$ of construction workers. Glyphosate and 2,4-D use was more common among sugarcane cutters whereas paraquat and the insecticides cypermethrin and chlorpyrifos were used more often by farmers. With the exception of cypermethrin, which had been used by almost half of the farmers, no specific pesticide exceeded $25 \%$ of users in any of the groups.
Status of kidney function and hydration by occupation

Kidney function biomarkers were more commonly abnormal among sugarcane cutters, with significant differences between the groups for prevalences of eGFR $<80 \mathrm{~mL} / \mathrm{min} / 1.73 \mathrm{~m}^{2}(16 \%, 9 \%$ and $2 \%$ in sugarcane cutters, construction workers and small-scale farmers, respectively; $\mathrm{p}$ for trend=0.003), high $\mathrm{SCr}$ ( $\mathrm{p}$ for trend $=0.02$ ) and high BUN ( $p$ for trend $=0.003$ ) (table $3 \mathrm{~A}$ ). Likewise, proteinuria $>30 \mathrm{mg} / \mathrm{dL}$ was approximately three times more prevalent in sugarcane workers than in the other groups $(15 \%$ vs $5-6 \%$, p for trend=0.08), whereas leucocyturia was observed in $22 \%$ of sugarcane workers but in only $0-2 \%$ of the other heat-exposed groups $(p<0.001)$. Microhaematuria was also three times more prevalent in sugarcane workers, but this difference was not statistically significant $(6 \%$ vs $2 \%, \mathrm{p}$ for trend=0.19). High S-UA was more common among sugarcane cutters $(17 \%)$ and construction workers $(16 \%)$ than among farmers $(6 \%)$.

Regarding markers of dehydration, the prevalence of concentrated urine (USG $\geq 1.030$ ) was not statistically different between groups (table 3B). Low urinary $\mathrm{pH}$ occurred in $29 \%$ of sugarcane cutters versus $12 \%$ of construction workers and farmers $(\mathrm{p}=0.01)$ and sugarcane

Table 3 Biomarkers of kidney function and dehydration among workers in three occupations and trend over categories ordered by exposure to occupational heat stress (sugarcane $>$ construction $>$ farming), municipalities of Chinandega and León, Nicaragua, 2013

\begin{tabular}{|c|c|c|c|c|c|}
\hline Variable & $\begin{array}{l}\text { Sugarcane } \\
(\mathrm{N}=86)\end{array}$ & $\begin{array}{l}\text { Construction } \\
(\mathrm{N}=56)\end{array}$ & $\begin{array}{l}\text { Farming } \\
(\mathrm{N}=52)\end{array}$ & $\begin{array}{l}\text { p Value: } \\
\text { differences } \\
\text { between groups* }\end{array}$ & $\begin{array}{l}\text { p Value: } \\
\text { trendt }\end{array}$ \\
\hline \multicolumn{6}{|l|}{ (A) Indicators of kidney function } \\
\hline BUN (mg/dL), mean \pm SD (range) & $\begin{array}{l}13.9 \pm 5.0 \ddagger \\
(6.0-28.4)\end{array}$ & $\begin{array}{l}10.1 \pm 5.1 \\
(4.1-30.0)\end{array}$ & $\begin{array}{l}9.2 \pm 3.6 \\
(4.0-22.0)\end{array}$ & $<0.001$ & \\
\hline BUN >20 mg/dL (\%) & $15.1 \neq$ & 5.4 & 1.9 & 0.017 & 0.003 \\
\hline $\begin{array}{l}\text { Serum creatinine }(\mathrm{SCr})(\mathrm{mg} / \mathrm{dL}) \text {, mean } \pm \mathrm{SD} \\
\text { (range) }\end{array}$ & $\begin{array}{l}0.84 \pm 0.39 \\
(0.44-2.39)\end{array}$ & $\begin{array}{l}1.00 \pm 1.16 \\
(0.49-8.84)\end{array}$ & $\begin{array}{l}0.78 \pm 0.22 \\
(0.51-1.83)\end{array}$ & 0.393 & \\
\hline $\mathrm{SCr}>1.2 \mathrm{mg} / \mathrm{dL}, \%$ & $17.4 \rrbracket$ & 8.9 & 5.81 & 0.088 & 0.024 \\
\hline eGFR ${ }_{C K D-E P I}$, mean $\pm S D$ (range) & $\begin{array}{l}121 \pm 31 \\
(34-160)\end{array}$ & $\begin{array}{l}118 \pm 30 \\
(7-161)\end{array}$ & $\begin{array}{l}125 \pm 18 \\
(49-158)\end{array}$ & 0.299 & \\
\hline$e^{\text {eGFR }}$ CKD-EPI $<80 \mathrm{~mL} / \mathrm{min} / 1.73 \mathrm{~m}^{2}, \%$ & $16.3 \rrbracket$ & 8.9 & 1.99 & 0.025 & 0.003 \\
\hline S-UA (mg/dL), mean \pm SD (range) & $\begin{array}{l}6.0 \pm 1.7 \\
(3.0-12.7)\end{array}$ & $\begin{array}{l}5.8 \pm 1.6 \\
(3.6-11.0)\end{array}$ & $\begin{array}{l}5.0 \pm 1.1 \neq \\
(2.9-8.1)\end{array}$ & 0.001 & \\
\hline S-UA >7.2 mg/dL, \% & 17.4 & 16.1 & 5.8 & 0.136 & 0.055 \\
\hline Proteinuria $>30 \mathrm{mg} / \mathrm{dL}, \%$ & 14.7 & 5.4 & 6.1 & 0.128 & 0.081 \\
\hline Leucocytes in urine, $\%$ & $22.1 \ddagger$ & 0 & 1.9 & $<0.001$ & $<0.001$ \\
\hline Nitrites in urine, $\%$ & 0 & 0 & 0 & - & - \\
\hline $\begin{array}{l}\text { Blood in urine, } \% \\
\text { (B) Indicators of dehydration }\end{array}$ & 5.8 & 1.8 & 1.9 & 0.339 & 0.186 \\
\hline Urinary specific gravity $\geq 1.030, \%$ & 15.3 & 28.6 & 20.4 & 0.161 & 0.255 \\
\hline Urinary $\mathrm{pH} \leq 5.5, \%$ & $29.4 \ddagger$ & 12.5 & 12.2 & 0.014 & 0.006 \\
\hline BUN/SCr ratio $>20, \%$ & $25.6 \ddagger$ & 0 & 3.8 & $<0.001$ & $<0.001$ \\
\hline \multicolumn{6}{|c|}{$\begin{array}{l}\text { *p Value for differences between groups: ANOVA for normally distributed continuous variables, Kruskal-Wallis for not normally distributed } \\
\text { continuous variables, } \chi^{2} \text { test for categorical variables. } \\
\text { †Gamma statistic for trend over ordered categories. } \\
\text { †Significantly different from the other two categories in post hoc tests. } \\
\text { ISignificant difference only between sugarcane cutters and construction workers. } \\
\text { BUN, blood urea nitrogen; eGFR, estimated glomerular filtration rate; SCr, serum creatinine; S-UA, serum uric acid. }\end{array}$} \\
\hline
\end{tabular}


cutters more commonly had an elevated BUN/SCr ratio (26\% vs 0 and $4 \%$ of construction workers and farmers, $\mathrm{p}<0.001)$. Trends over ordered categories were significant for urinary $\mathrm{pH}$ and $\mathrm{BUN} / \mathrm{SCr}$ ratio. Although sugarcane cutters as a group had a lower prevalence of concentrated urine, within the group low fluid intake was strongly associated with concentrated urine (OR 3.5, $\mathrm{p}=0.06$ ) and acidic urine (OR 8.7, $\mathrm{p}<0.001$ ), which was not the case among construction workers and farmers (table 4).

\section{Risk factors for reduced kidney function}

In bivariate analyses of differences in kidney, urinary and metabolic biomarkers, work practices, hydration practices and lifestyle characteristics between subjects with reduced kidney function (eGFR $<80 \mathrm{~mL}$ / $\min / 1.73 \mathrm{~m}^{2}$ ) and subjects with normal kidney function (eGFR $\geq 80 \mathrm{~mL} / \mathrm{min} / 1.73 \mathrm{~m}^{2}$ ) (see online supplementary table S1), reduced kidney function was significantly associated with work as a sugarcane cutter, high intake of water, low intake of sugary beverages, increasing age, low haemoglobin and high tobacco consumption. In analyses restricted to sugarcane cutters the results were similar and, in addition, workers with reduced kidney function had cut cane for a considerably longer time than those with normal kidney function (cumulative time on the job: median 108 vs 60 months, $\mathrm{p}=0.06)$. Sugarcane cutters with reduced kidney function reported almost three times higher water intake and three times lower intake of sugary beverages than cutters with normal kidney function, with only one of the 14 reporting intake of the electrolyte solution. In addition, the cane cutters with reduced kidney function had a worse lipid profile than those with normal kidney function and more often had hypertension, but none had diabetes or hyperglycaemia and only one was overweight (see online supplementary table S1).

In backwards stepping multivariate linear regression analyses with inclusion of variables with $\mathrm{p} \leq 0.10$ in the bivariate analyses (except haemoglobin due to missing data), age $(\beta-1.3,95 \%$ CI -1.8 to $-0.8 ; \mathrm{p}<0.001)$ and S-UA $(\beta-10.4,95 \%$ CI -12.2 to $-8.5 ; p<0.001)$ were significantly associated with reduced kidney function among all workers, which was identical in models with total fluid intake and with intake of water and sugary beverages separately (table $5 \mathrm{~A}$ ). In the subset of sugarcane cutters, too many variables had a $p$ value $\leq 0.10$ in bivariate analyses (see online supplementary table S1) and therefore the regression was done in two steps. Hypertension, lipid profile tests and blood sugar were not associated with reduced kidney function in a model also including age and S-UA (data not shown) and were not further considered. In a model with water intake, intake of sugary drinks (without electrolyte solution) and intake yes/no of electrolyte solution, age, S-UA, high tobacco consumption and high alcohol consumption (table 5B), reduced kidney function was associated significantly with age and S-UA and non-significantly with the intake of electrolyte solution ( $\beta$ 8.1, 95\% CI -1.2 to $17.5, \mathrm{p}=0.09)$. Age and cumulative months on the job correlated $\left(r_{p} 0.68, p<0.001\right)$, and substituting age with time cutting cane yielded similar results.

\section{DISCUSSION}

This study found evidence for more frequent heat stress, dehydration and kidney dysfunction among sugarcane

Table 4 Associations between low intake of fluids and markers of dehydration among sugarcane cutters $(n=86)$ and non-cutters (construction workers and small-scale farmers) $(n=108)$

\begin{tabular}{|c|c|c|c|}
\hline Lowest quartiles of fluid intake & $\begin{array}{l}\text { USG } \geq 1.030^{*} \\
\text { OR }(95 \% \mathrm{CI}) \\
\text { p Value† }\end{array}$ & $\mathrm{pH} \leq 5.5^{\star}$ & BUN/SCr ratio > $20^{*}$ \\
\hline \multicolumn{4}{|l|}{ Total fluids $\leq 2.5 \mathrm{~L}$} \\
\hline Sugarcane cutters $(n=16)$ & $\begin{array}{l}3.5(1.0 \text { to } 13) \\
p=0.06\end{array}$ & $\begin{array}{l}8.7(2.6 \text { to } 29) \\
p<0.001\end{array}$ & $\begin{array}{l}1.2(0.3 \text { to } 4.3) \\
p=0.67\end{array}$ \\
\hline Construction workers and farmers $(n=32)$ & $\begin{array}{l}1.4(0.5 \text { to } 3.5) \\
p=0.51\end{array}$ & $\begin{array}{l}2.3(0.7 \text { to } 7.5) \\
p=0.17\end{array}$ & $-\ddagger$ \\
\hline \multicolumn{4}{|l|}{ Water $\leq 1.5 \mathrm{~L}$} \\
\hline Sugarcane cutters $(n=16)$ & $\begin{array}{l}3.0(0.7 \text { to } 12) \\
p=0.14\end{array}$ & $\begin{array}{l}2.9(0.9 \text { to } 9.6) \\
p=0.08\end{array}$ & $\begin{array}{l}2.3(0.7 \text { to } 7.3) \\
p=0.17\end{array}$ \\
\hline Construction workers and farmers $(n=32)$ & $\begin{array}{l}1.9(0.7 \text { to } 4.9) \\
p=0.18\end{array}$ & $\begin{array}{l}1.7(0.5 \text { to } 5.6) \\
p=0.42\end{array}$ & $-\ddagger$ \\
\hline \multicolumn{4}{|l|}{ Sugary drinks $\leq 0.75 \mathrm{~L}$} \\
\hline Sugarcane cutters $(n=28)$ & $\begin{array}{l}2.5(0.7 \text { to } 9.2) \\
p=0.16\end{array}$ & $\begin{array}{l}2.5(0.9 \text { to } 7.1) \\
p=0.08\end{array}$ & $\begin{array}{l}0.3(0.2 \text { to } 1.1) \\
p=0.06\end{array}$ \\
\hline Construction workers and farmers $(n=21)$ & $\begin{array}{l}1.8(0.6 \text { to } 5.2) \\
p=0.28\end{array}$ & $\begin{array}{l}0.7(0.2 ; 3.6) \\
p=0.69\end{array}$ & $-\ddagger$ \\
\hline
\end{tabular}


Table 5 Multivariate linear regression models of estimated glomerular filtration rate (eGFR $\mathrm{CKD}_{\text {-EPI }}$ ) among all workers (sugarcane cutters, construction workers and farmers) and restricted to sugarcane cutters

\begin{tabular}{|c|c|c|c|c|}
\hline & $\begin{array}{l}\text { B coefficient } \\
(95 \% \mathrm{Cl})\end{array}$ & $\begin{array}{l}\text { Standardised } \\
\beta \text { coefficient }\end{array}$ & p Value & Adjusted $\mathbf{R}^{2}$ \\
\hline \multicolumn{5}{|l|}{ (A) All subjects $(N=194)$} \\
\hline \multicolumn{5}{|l|}{ Step 1} \\
\hline Water intake (L) & $-0.7(-1.7$ to 0.3$)$ & -0.08 & 0.15 & 0.47 \\
\hline Sugary beverages intake (L) & $1.2(-0.8$ to 3.3$)$ & 0.06 & 0.24 & \\
\hline Sugarcane cutter ever & $3.6(-2.5$ to 9.6$)$ & 0.07 & 0.25 & \\
\hline Age (years) & $-1.2(-1.7$ to -0.6$)$ & -0.24 & $<0.001$ & \\
\hline Serum uric acid (mg/dL) & $-10.0(-12.0$ to -8.1$)$ & -0.57 & $<0.001$ & \\
\hline High tobacco consumption & $-4.5(-11.6$ to 2.7$)$ & -0.07 & 0.22 & \\
\hline High alcohol consumption & $1.2(-5.6$ to 8.1$)$ & 0.02 & 0.72 & \\
\hline \multicolumn{5}{|l|}{ Final step } \\
\hline Age (years) & $-1.3(-1.8$ to -0.8$)$ & -0.27 & $<0.001$ & 0.47 \\
\hline Serum uric acid (mg/dL) & $-10.4(-12.2$ to -8.5$)$ & -0.59 & $<0.001$ & \\
\hline \multicolumn{5}{|l|}{ (B) Sugarcane cutters $(N=86)$} \\
\hline \multicolumn{5}{|l|}{ Step 1} \\
\hline Water intake (L) & $-0.7(-1.9$ to 0.5$)$ & -0.09 & 0.25 & 0.58 \\
\hline Sugary beverages intake (without electrolyte solution) (L) & $1.2(-3.7$ to 6.0$)$ & 0.04 & 0.63 & \\
\hline Electrolyte solution (yes/no) & $6.4(-4.5$ to 17.3$)$ & 0.10 & 0.24 & \\
\hline Age (years) & $-1.7(-2.5$ to -0.8$)$ & -0.29 & $<0.001$ & \\
\hline Serum uric acid & $-10.9(-13.8:-8.1)$ & -0.59 & $<0.001$ & \\
\hline High tobacco consumption & $-10.1(-22.5$ to 2.3$)$ & -0.12 & 0.11 & \\
\hline High alcohol consumption & $-7.8(-19.5$ to 3.9$)$ & -0.10 & 0.19 & \\
\hline \multicolumn{5}{|l|}{ Final step } \\
\hline Age (years) & $-1.9(-2.7$ to -1.1$)$ & -0.34 & $<0.001$ & 0.57 \\
\hline Serum uric acid (mg/dL) & $-11.3(-14.0$ to -8.6$)$ & -0.61 & $<0.001$ & \\
\hline Electrolyte solution (yes/no) & $8.1(-1.2$ to 17.5$)$ & 0.13 & 0.09 & \\
\hline
\end{tabular}

cutters, as expected, and to a lesser degree also reduced kidney function among construction workers but not among small-scale farmers. Also, as expected, S-UA levels increased with decreasing eGFR.

\section{Evidence of reduced kidney function}

We used a cut-off of eGFR of $80 \mathrm{~mL} / \mathrm{min} / 1.73 \mathrm{~m}^{2}$ to evaluate differences in renal function because only 11 workers had eGFR $<60$ due to their young age (all under age 40) and also because sugarcane workers were screened by employers before the start of the harvest 2 months earlier and workers with $\mathrm{SCr}>1.2 \mathrm{mg} / \mathrm{dL}$ were not hired and, thus, were not part of our study population. Despite this, approximately one-quarter of sugarcane cutters had evidence for either eGFR $<80 \mathrm{~mL} /$ $\min / 1.73 \mathrm{~m}^{2}, \mathrm{SCr}>1.2 \mathrm{mg} / \mathrm{dL}$ or proteinuria $\geq 30 \mathrm{mg}$, and these findings were, respectively, eight-, three- and twofold more common than those observed in subsistence farmers and about twofold more common than in construction workers (table 3). However, although to a lesser degree than cane cutters, construction workers also had an unusually high prevalence of decreased kidney function, which is in accordance with a previous unpublished study in the same area. ${ }^{25}$ In contrast, the single small-scale farmer with reduced kidney function had worked previously in sugarcane. Thus, our results show that not all agricultural workers are at increased risk for CKD, as is commonly stated, but rather workers in certain types of agriculture and other jobs in the heat such as work in the construction industry. The absence of reduced kidney function among subsistence farmers is consistent with a study in a MeN epidemic area in $\mathrm{El}$ Salvador, where subsistence farmers without a history of plantation work had a significantly lower prevalence of abnormal SCr than men who had worked on sugar or cotton plantations ( $15 \%$ vs $33 \%) .{ }^{20}$ Reduced kidney function was accompanied by a higher frequency of anaemia among sugarcane cutters $(36 \%$ vs $4-9 \%$ in the other groups). The prevalence of anaemia was higher than the prevalence of reduced kidney function and cannot be simply ascribed to the higher frequency of reduced renal function. Marked anaemia, defined as $\mathrm{Hb}$ $<10 \mathrm{~g} / \mathrm{dL}$, was not observed in any of the groups.

Reduced kidney function was not associated with traditional risk factors for CKD. Notably, there were no cases of confirmed diabetes in the entire population. Importantly, sugarcane workers showed significantly worse renal function despite an overall lower frequency of abnormal lipid profile, hypertension and obesity compared with the other two groups (see table 1). Increasing age ( $>50$ years) is a known risk factor for CKD, but in our study increasing age was associated with a decline in renal function despite the young age of the study participants. This is possibly related to an increased risk with continued job exposure over time, in particular among the sugarcane cutters. Thus, our study 
suggests that most cases of reduced kidney function are related to $\mathrm{MeN}$ and not classic CKD.

\section{Evidence for heat stress}

There was evidence for a greater risk of heat stress among sugarcane cutters. Sugarcane cutters laboured at a faster pace, had less exposure to shade, reported more weight loss during the ongoing harvest and had more fainting episodes. While sugarcane cutters had greater heat stress exposure, they also drank more fluids during the course of the day, amounting to an average of $6.2 \mathrm{~L}$ per day (although this varied considerably, with approximately $20 \%$ drinking $<2.5 \mathrm{~L} /$ day and $40 \%>7 \mathrm{~L} /$ day). However, the type of exertion and sweating that occurs with cane harvesting ${ }^{11-13}$ could still result in a dramatic loss of fluids such that dehydration can occur despite high fluid consumption. Cade $e t a l^{28}$ found that college football players could lose as much as 8 quarts (about 7.6 L) of water in a 2-hour period, associated with loss of salt, decrease in blood glucose and a fall in blood pressure.

\section{Potential mechanisms involved in inducing kidney damage}

Daily heat stress and dehydration may cause repeated renal hypoperfusion episodes, and intermittent subclinical rhabdomyolysis associated with excessive exertion may also induce repeated acute kidney injury through the release of inflammatory mediators including oxidants, cytokines and uric acid which, over time, leads to CKD. ${ }^{18}$ Experimental evidence has shown that repeated exposure to heat stress caused a reduction in renal function accompanied by histological evidence of tubulointerstitial damage. ${ }^{19}$ Heat stress is known to raise S-UA levels, in part from subclinical rhabdomyolysis ${ }^{29}$ but also from reduced renal blood flow. ${ }^{30}$ In turn, hyperuricaemia is a well-known risk factor for $\mathrm{CKD}^{31}$ and mediates both glomerular and tubulointerstitial disease in animals. ${ }^{32-34}$ Interestingly, S-UA levels tended to be highest in both sugarcane workers and construction workers, with $16-17 \%$ of these individuals having hyperuricaemia compared with $6 \%$ of subsistence farmers. Furthermore, we found that the presence of hyperuricaemia was independently and strongly associated with declining renal function - that is, for each increase of $1 \mathrm{mg} / \mathrm{dL}$ S-UA there was an average decline of $10 \mathrm{~mL} /$ min in kidney filtration (see table 5). However, since reduced renal function can also result in increased uric acid levels due to impaired excretion, the causal role of uric acid in reduced kidney function cannot be determined.

Recently we hypothesised that renal injury could be occurring in sugarcane workers due to cyclical uricosuria with crystal formation. ${ }^{20}{ }^{21}$ According to this hypothesis, S-UA might rise as a consequence of subclinical rhabdomyolysis, followed by its crystallisation in the urine. One factor that increases the risk of urate crystal formation is acidic urine, which could result from the release of lactic acid associated with strenuous exercise and the effects of dehydration to reclaim sodium with hydrogen ion excretion. Urine $\mathrm{pH}$ was significantly lower in the sugarcane workers compared with the other groups (see table 3 ) and was strongly associated with low fluid intake on the previous (work) day in the subset of sugarcane workers (see table 4). This might reflect the effects of greater volume depletion (with aldosterone stimulation), lactic acid generation during the previous day, or other mechanisms.

\section{Hydration and fructose}

We had expected that low water intake or high sugary fluid intake would be associated with reduced renal function, based on studies in animals. ${ }^{19} 35$ However, workers with eGFR $<80 \mathrm{~mL} / \mathrm{min} / 1.73 \mathrm{~m}^{2}$ drank more water and consumed fewer sugar-based drinks during the workday than subjects with normal kidney function ( 4.5 vs $2.2 \mathrm{~L}$ water, $\mathrm{p}=0.08$; 0.6 vs $1.25 \mathrm{~L}$ sugary beverages, $\mathrm{p}=0.001$ ) (see online supplementary table $\mathrm{S} 1$ ). This was particularly so among the sugarcane cutters with reduced kidney function who drank about $4 \mathrm{~L}$ more water and $1 \mathrm{~L}$ less sugary beverages. Excessive thirst from decreased concentration capacity of impaired kidneys may partially explain these counterintuitive findings, as well as the very high water requirements during the heavy labour of sugarcane cutting. ${ }^{12}{ }^{13}$ Although low fluid intake was clearly associated with concentrated urine among sugarcane cutters (USG $\geq 1.030$ : OR 3.5, $\mathrm{p}=0.06$ ) (see table 4), cutters in the quartile with the highest fluid intake did not have a decreased risk of concentrated urine (OR 1.3, $\mathrm{p}=0.70$ ) while high fluid intake among non-sugarcane workers appeared to be preventive $(\mathrm{OR} 0.10, \mathrm{p}=0.06)$. Salvadorian cane cutters who consumed amounts of fluid comparable to the Nicaraguan cutters were found to have insufficient fluid intake under their work conditions. ${ }^{11}$

Sugary beverages that contain fructose are known to increase the risk of albuminuria ${ }^{36}$ and can induce renal injury in laboratory animals. ${ }^{35}$ However, fructose is also a component of sports drinks and fluid resuscitation packets containing glucose and electrolytes that might be beneficial to the volume and water depleted, such as by providing glucose that may prevent or treat any associated hypoglycaemia or by helping to maintain blood pressure due to the fructose component. ${ }^{37} 38$ In our study, the intake of electrolyte solutions tended to be associated $(p=0.09)$ with improved kidney function in multivariate analyses (see table 5). One study in Nicaragua found that, for each $100 \mathrm{~mL}$ electrolyte hydration packet consumed during the workday, the eGFR of cane cutters increased by $7 \mathrm{~mL} / \mathrm{min} / 1.73 \mathrm{~m}^{2}$ over the course of one harvest season. ${ }^{17}$ These issues need to be assessed with prospective studies that examine overall fluid balance by measuring fluid intake as well as losses during work, such as pre- and post-shift weight and serum and urine osmolarity. 


\section{Other risk factors for kidney disease}

There was no association with NSAIDs or alcohol intake. A history of high tobacco consumption was more frequent among subjects with reduced kidney function $(p=0.02)$ but lost significance in multivariate analyses. A history of pesticide exposure was more common among farmers, although exposure to herbicides was more common among sugarcane cutters, especially glyphosate and 2,4-D, both of special interest. However, analyses failed to identify pesticide exposures as an independent risk factor for reduced kidney function (see online supplementary table $\mathrm{S} 1$ ).

\section{Study limitations}

The main limitation of our study is its cross-sectional design. The kidney function parameters are based on single determinations in blood and urine without a chronicity criterion (presence during at least 3 months) for a proper clinical diagnosis of CKD. ${ }^{39}$ Recently, attention has been drawn to the fact that single biomarker determinations and consequent categorisations into CKD stages based on a cut-off value, without consideration of age- and sex-specific criteria for GFR, are inadequate as the basis for population-based CKD prevalences because these practices can lead to overdiagnosis among the elderly and underdiagnosis in younger age groups, with large unexplained differences between nations. ${ }^{40}$ However, the main purpose of our study is not a clinical diagnosis but to distinguish differences in kidney function parameters between three occupational groups of the same sex and same young age distribution, and comparisons therefore remain valid on the group level. In addition, in the same region, at the time of this study, we also followed a small group of heat-exposed sugarcane cutters and a group of control workers unexposed to heat over the harvest season. The cutters showed an important decline in kidney function, ${ }^{42}$ which provides support for the cross-sectional findings, although no cohort data exist for construction workers or farmers.

Another limitation is that our heat exposure and hydration data were self-reported, but these data were collected through carefully designed questionnaires. Workers were asked to fast and did not consume any food before providing blood and spot urine samples between 05:30 and 06:00 hours (see Methods), but they did ingest water or other fluids during the evening, night and early morning. Nonetheless, we observed a lower U-pH and more frequent high $\mathrm{BUN} / \mathrm{SCr}$ ratio among cane cutters and, to a lesser extent, among construction workers compared with subsistence farmers, which is an indication of incomplete recovery of adequate hydration status after the previous work day among the more heat stress-exposed workers.

Our sample size was based on a pre-study power calculation of $80 \%$ to detect CKD among 100 sugarcane cutters and100 non-cutters at $\alpha 0.05$. Post hoc, we achieved a power of 0.68 for an increased risk of reduced eGFR among cutters versus non-cutters, but the post hoc power of the comparison between cutters and farmers was $80 \%$. Therefore, our results seem sufficiently reliable, also considering the significant trends for indicators of heat stress, dehydration and kidney dysfunction in support of our main hypothesis of cane cutting $>$ construction $>$ farming. Finally, we did not have resources for examining biomarkers of early damage such as neutrophil gelatinase associated lipocalin (NGAL) and N-acetyl- $\beta$-D-glucosaminidase (NAG), which are important to include in future studies.

\section{CONCLUSIONS}

Compared with construction workers and, in particular, subsistence farmers from the same MeN epidemic region of Nicaragua, sugarcane cutters have higher heat stress, more dehydration and worse renal function despite the fact that other health indicators of the cutters were significantly better. Our study supports the need for improved work practices and even more hydration with adequate access to water for sugarcane cutters, as well as for workers in other hot occupations such as construction. The associations between intake of water and sugary drinks and kidney function as well as the role of hyperuricaemia need to be assessed in carefully designed follow-up studies.

\section{Author affiliations}

${ }^{1}$ Unit of Occupational Medicine, Institute of Environmental Medicine (IMM), Karolinska Institutet, Stockholm, Sweden

${ }^{2}$ Research Research Centre on Health, Work and Environment (CISTA), National Autonomous University of Nicaragua, León, Nicaragua

${ }^{3}$ Department of Non-communicable Disease Epidemiology, London School of Hygiene and Tropical Medicine, London, UK

${ }^{4}$ La Isla Foundation, Chicago, Illinois, USA

${ }^{5}$ Division of Renal Diseases and Hypertension, University of Colorado, Aurora, Colorado, USA

${ }^{6}$ Department Nephrology and Mineral Metabolism, National Medical Science and Nutrition Institute Salvador Zubirán, Mexico City, Mexico

Contributors Concept and design: AA, CW, MG, RJJ, JG, RC-R. Data collection and biological analyses: AA, MG, IW, CR-J, CJR. Data analysis: CW. Data interpretation: All authors. Manuscript preparation: CW, RJJ. Critical revision and approval of manuscript: All authors.

Funding Danone Research, Palaiseau, France. The funder did not participate in study design, data collection or reporting of results.

Competing interests None declared.

Patient consent Obtained.

Ethics approval Ethical Review Board of the National Autonomous University of Nicaragua, León, Nicaragua.

Provenance and peer review Not commissioned; externally peer reviewed.

Data sharing statement No additional data are available.

Open Access This is an Open Access article distributed in accordance with the Creative Commons Attribution Non Commercial (CC BY-NC 4.0) license, which permits others to distribute, remix, adapt, build upon this work noncommercially, and license their derivative works on different terms, provided the original work is properly cited and the use is non-commercial. See: http:// creativecommons.org/licenses/by-nc/4.0/ 


\section{REFERENCES}

1. Wesseling C, Crowe J, Hogstedt C, et al. Resolving the enigma of the Mesoamerican nephropathy-MeN-a research workshop summary. Am J Kidney Dis 2014;63:396-404.

2. Wijkström J, Leiva R, Elinder CG, et al. Clinical and pathological characterization of Mesoamerican nephropathy: a new kidney disease in Central America. Am J Kidney Dis 2013;62:908-18.

3. Ramirez-Rubio O, McClean MD, Amador JJ, et al. An epidemic of chronic kidney disease in Central America: an overview. J Epidemio Community Health 2013;67:1-3.

4. Correa-Rotter R, Wesseling C, Johnson RJ. CKD of unknown origin in Central America: the case for a Mesoamerican nephropathy. Am J Kidney Dis 2014;63:506-20.

5. Torres C, Aragón A, González M, et al. Decreased kidney function of unknown cause in Nicaragua: a community-based survey. Am J Kidney Dis 2010;55:485-96.

6. Vela XF, Henríquez DO, Zelaya SM, et al. Chronic kidney disease and associated risk factors in two Salvadoran farming communities, 2012. MEDICC Rev 2014;16:55-60.

7. Orantes CM, Herrera R, Almaguer M, et al. Chronic kidney disease and associated risk factors in the Bajo Lempa region of El Salvador: Nefrolempa study, 2009. MEDICC Rev 2011;13:14-22.

8. Jayasinghe $\mathrm{S}$. Chronic kidney disease of unknown etiology should be renamed chronic agrochemical nephropathy. MEDICC Rev 2014;16:72-4.

9. Wesseling C, Crowe J, Hogstedt C, et al. The epidemic of chronic kidney disease of unknown etiology in Mesoamerica: a call for interdisciplinary research and action. Am J Public Health 2013;103:1927-30.

10. Wesseling C, van Wendel de Joode B, Crowe J, et al. Mesoamerican nephropathy: geographical distribution and time trends of chronic kidney disease mortality between 1970 and 2012 in Costa Rica. Occup Environ Med 2015;72:714-21.

11. García-Trabanino R, Jarquín E, Wesseling C, et al. Heat stress, dehydration, and kidney function in sugarcane cutters in El Salvador - a cross-shift study of workers at risk of Mesoamerican nephropathy. Environ Res 2015;142:746-55.

12. Crowe J, Wesseling $\mathrm{C}$, Román-Solano B, et al. Heat exposure in sugarcane harvesters in Costa Rica. Am $\mathrm{J}$ Ind Med 2013;56:1157-64.

13. Lucas RA, Bodin T, García-Trabanino R, et al. Heat stress and workload associated with sugarcane cutting - an excessively strenuous occupation! Extrem Physiol Med 2015;4(Suppl 1):A23.

14. Raines N, González M, Wyatt C, et al. Risk factors for reduced glomerular filtration rate in a Nicaraguan community affected by Mesoamerican nephropathy. MEDICC Rev 2014;16:16-22.

15. Ramirez-Rubio O, Brooks DR, Amador JJ, et al. Chronic kidney disease in Nicaragua: a qualitative analysis of semi-structured interviews with physicians and pharmacists. BMC Public Health 2013;13:350.

16. Jayasumana C, Fonseka S, Fernando A, et al. Phosphate fertilizer is a main source of arsenic in areas affected with chronic kidney disease of unknown etiology in Sri Lanka. Springerplus 2015;4:90.

17. Laws RL, Brooks DR, Amador JJ, et al. Changes in kidney function among Nicaraguan sugarcane workers. Int J Occup Environ Health 2015;21:241-50.

18. Paula Santos U, Zanetta DM, Terra-Filho M, et al. Burnt sugarcane harvesting is associated with acute renal dysfunction. Kidney Int 2015;87:792-9.

19. Roncal-Jimenez CA, Ishimoto T, Lanaspa MA, et al. Fructokinase activity mediates dehydration-induced renal injury. Kidney Int 2014;86:294-302.

20. Roncal-Jimenez C, Lanaspa MA, Jensen T, et al. Mechanisms by which dehydration may lead to chronic kidney disease. Ann Nutr Metab 2015;66(Suppl 3):P10-13.

21. Roncal-Jimenez C, García-Trabanino R, Barregard L, et al. Heat stress nephropathy from exercise-induced uric acid crystalluria: a perspective on Mesoamerican nephropathy. Am J Kidney Dis 2016;67:20-30.
22. McClean MA, Amador JJ, Laws R, et al. Biological sampling report: Investigating biomarkers of kidney injury and chronic kidney disease among workers in Western Nicaragua. Boston: University School of Public Health: Compliance Advisor Ombudman, 2012. http://www. cao-ombudsman.org/documents/Biological_Sampling_Report_April_ 2012.pdf (accessed 2 Jan 2016).

23. Peraza S, Wesseling C, Aragón A, et al. Decreased kidney function among agriculture workers in El Salvador. Am J Kidney Dis 2012;59:531-40.

24. Crowe J, Nilsson M, Kjellström T, et al. Heat-related symptoms in sugarcane harvesters. Am J Ind Med 2015;58:541-8.

25. Madero M, Arriaga JC, Jalal D, et al. The effect of two energy-restricted diets, a low-fructose diet versus a moderate natura fructose diet, on weight loss and metabolic syndrome parameters: a randomized controlled trial. Metab Clin Exp 2011;60:1551-9.

26. Agricultural Research Service. National Nutrient Database for Standard Reference Release 27. United States Department of Agriculture. http://ndb.nal.usda.gov/ndb/foods/show/6216? $\mathrm{fg}=\& \mathrm{man}=\&$ lfacet=\&count=\&max=25\&sort=\&qlookup=cane\& offset=\&format=Full\&new=\&measureby (accessed 2 Jan 2016).

27. Franke TM, Ho T, Christie CA. The chi-square test: often used and more often misinterpreted. Am J Evaluation 2012;33:448-58.

28. Cade JR, Free HJ, De Quesada AM, et al. Changes in body fluid composition and volume during vigorous exercise by athletes. J Sports Med Phys Fitness 1971;11:172-8.

29. Vanholder R, Sever MS, Erek E, et al. Rhabdomyolysis. J Am Soc Nephrol 2000;11:1553-61.

30. Knochel JP, Dotin LN, Hamburger RJ. Heat stress, exercise, and muscle injury: effects on urate metabolism and renal function. Ann Intern Med 1974;81:321-8.

31. Johnson RJ, Nakagawa T, Jalal D, et al. Uric acid and chronic kidney disease: which is chasing which? Nephrol Dial Transplant 2013;28:2221-8.

32. Nakagawa T, Mazzali M, Kang DH, et al. Hyperuricemia causes glomerular hypertrophy in the rat. Am J Nephrol 2003;23:2-7.

33. Kang DH, Nakagawa T, Feng $L$, et al. A role for uric acid in the progression of renal disease. J Am Soc Nephrol 2002;13:2888-97.

34. Sánchez-Lozada LG, Tapia E, Santamaría J, et al. Mild hyperuricemia induces vasoconstriction and maintains glomerular hypertension in normal and remnant kidney rats. Kidney Int 2005;67:237-47.

35. Gersch MS, Mu W, Cirillo $\mathrm{P}$, et al. Fructose, but not dextrose, accelerates the progression of chronic kidney disease. Am J Physiol Renal Physiol 2007;293:F1256-61.

36. Shoham DA, Durazo-Arvizu R, Kramer H, et al. Sugary soda consumption and albuminuria: results from The National Health and Nutrition Examination Survey, 1999-2004. PLoS ONE 2008;3:e3431.

37. Le MT, Frye RF, Rivard CJ, et al. Effects of high-fructose corn syrup and sucrose on the pharmacokinetics of fructose and acute metabolic and hemodynamic responses in healthy subjects. Metab Clin Exp 2012;61:641-51.

38. Brown CM, Dulloo AG, Yepuri G, et al. Fructose ingestion acutely elevates blood pressure in healthy young humans. Am J Physiol Regul Integr Comp Physiol 2008;294:R730-7.

39. Stevens PE, Levin A, Kidney Disease: Improving Global Outcomes Chronic Kidney Disease Guideline Development Work Group Members. Evaluation and management of chronic kidney disease: synopsis of the kidney disease: improving global outcomes 2012 clinical practice guideline. Ann Intern Med 2013;158:825-30.

40. Benghanem Gharbi M, Elseviers M, Zamd M, et al. Chronic kidney disease, hypertension, diabetes, and obesity in the adult population of Morocco: how to avoid "over"- and "under"-diagnosis of CKD. Kidney Int 2016;89:1363-71.

41. De Broe ME, Gharbi MB, Elseviers M. Maremar, prevalence of chronic kidney disease, how to avoid over-diagnosis and under-diagnosis. Nephrol Ther 2016;12(Suppl 1):S57-63.

42. Wesseling C, Aragón A, González M, et al. Kidney function in sugarcane cutters in Nicaragua-a longitudinal study of workers at risk of Mesoamerican nephropathy. Environ Res 2016;147:125-32. 


\section{Correction}

Wesseling C, Aragón A, González M, et al. Heat stress, hydration and uric acid: a crosssectional study in workers of three occupations in a hotspot of Mesoamerican nephropathy in Nicaragua. BMJ Open 2016;6:e011034.

There is a mistake in the layout of Table 2, beginning in Part B. The main categories should be: (A) Current occupational heat stress, (B) Fluid and fructose intake and $(\mathrm{C})$ Work and pesticide use history. The correct table layout is shown below:

\begin{tabular}{|c|c|c|c|c|}
\hline & $\begin{array}{l}\text { Sugarcane } \\
(\mathrm{N}=86)\end{array}$ & $\begin{array}{l}\text { Construction } \\
(\mathrm{N}=56)\end{array}$ & $\begin{array}{l}\text { Farming } \\
(\mathrm{N}=52)\end{array}$ & P-value* \\
\hline \multicolumn{5}{|l|}{ A. Current occupational heat stress } \\
\hline $\begin{array}{l}\text { Effective work hours per day (work hours } \\
\text { minus breaks), mean } \pm S D\end{array}$ & $6.5 \pm 1.2 \dagger$ & $8.1 \pm 0.7 \dagger$ & $5.3 \pm 2.0 \dagger$ & $<0.001$ \\
\hline Very rapid work pace, \% & $74.4 \dagger$ & 53.6 & 40.4 & $<0.001$ \\
\hline No shade during breaks, \% & $20.9 \ddagger$ & $1.8 \ddagger$ & 11.5 & 0.004 \\
\hline Lifting weights >50 lbs., $\%$ & $18.6 \dagger$ & 66.1 & 65.4 & $<0.001$ \\
\hline Awkward work postures, \% & 58.1 & 76.8 & 69.2 & 0.063 \\
\hline Incentives to cut more cane, $\%$ & 82.6 & - & - & - \\
\hline \multicolumn{5}{|l|}{ Hours post-burning at field entrance, } \\
\hline $\begin{array}{l}\text { Self-reported weight loss on the current } \\
\text { job (last two months), \% }\end{array}$ & $77.9 \dagger$ & 39.3 & 36.5 & $<0.001$ \\
\hline Fainted at work, \% & 5.8 & 0 & 1.9 & 0.126 \\
\hline Dysuria ('chistata'), \% & 43.0 & 48.2 & 44.2 & 0.827 \\
\hline \multicolumn{5}{|l|}{ B. Fluid and fructose intake } \\
\hline \multicolumn{5}{|l|}{ Fluid intake previous day (workday) } \\
\hline Total fluid $(\mathrm{L})$, mean $\pm \mathrm{SD}$ & $6.2 \pm 4.1 \dagger$ & $4.4 \pm 2.1$ & $4.0 \pm 2.7$ & 0.003 \\
\hline Water & $4.4 \pm 3.9 \dagger$ & $2.9 \pm 2.1$ & $2.8 \pm 2.4$ & 0.002 \\
\hline \multicolumn{5}{|l|}{ Sugary drinks without electrolyte } \\
\hline hydration solution & $1.8 \pm 1.8$ & $1.5 \pm 0.9$ & $1.2 \pm 0.8$ & 0.208 \\
\hline Electrolyte solution $(\mathrm{N}=31)$ & $1.2 \pm 1.1$ & - & - & - \\
\hline Lowest quartile total fluid ( $\leq 2.5 \mathrm{~L})$, \% & 18.6 & 19.6 & $40.4 \dagger$ & 0.009 \\
\hline Highest quartile total fluid ( $\geq 7.0 \mathrm{~L}$ ), \% & $40.7 \dagger$ & 8.9 & 13.5 & $<0.001$ \\
\hline \multicolumn{5}{|c|}{ Fluid intake on typical non-work day } \\
\hline Total fluid $(L)$, mean $\pm S D$ & $4.2 \pm 2.3$ & $3.8 \pm 1.7$ & $4.1 \pm 2.2$ & 0.503 \\
\hline Water & $3.0 \pm 2.0$ & $2.2 \pm 1.3$ & $2.7 \pm 2.0$ & 0.053 \\
\hline Sugary drinks & $1.2 \pm 1.1$ & $1.6 \pm 1.1$ & $1.4 \pm 1.9$ & 0.117 \\
\hline \multicolumn{5}{|c|}{ Fructose intake previous day (workday) } \\
\hline Total fructose intake $(\mathrm{g})$, mean $\mathrm{SD}$ & $103.1 \pm 72.1 \dagger$ & $80.1 \pm 46.1$ & $70.9 \pm 36.8$ & 0.008 \\
\hline From food sources & $8.4 \pm 10.7 \dagger$ & $15.9 \pm 16.6$ & $17.4 \pm 16.7$ & $<0.001$ \\
\hline From added sugar & $94.7 \pm 70.5 \dagger$ & $64.2 \pm 38.1$ & $53.2 \pm 30.7$ & $<0.001$ \\
\hline During work hours & $58.6 \pm 44.7 \dagger$ & $28.6 \pm 21.4$ & $26.1 \pm 16.5$ & $<<0.001$ \\
\hline $\begin{array}{l}\text { Sugary drinks ('frescos', sodas, } \\
\text { coffee) }\end{array}$ & $22.5 \pm 15.7$ & $28.6 \pm 21.4$ & $26.1 \pm 16.3$ & 0.108 \\
\hline Sugarcane chewing $(\mathrm{N}=53)$ & $35.0 \pm 18.5$ & - & - & - \\
\hline Electrolyte solution $(\mathrm{N}=31)$ & $40.3 \pm 35.2$ & - & - & - \\
\hline Outside (before and after) work hours & $36.1 \pm 39.3$ & $35.6 \pm 31.4$ & $27.1 \pm 25.9$ & 0.350 \\
\hline $\begin{array}{l}\text { Highest quartile total fructose intake } \\
(>107 \mathrm{~g}), \%\end{array}$ & $40.7 \dagger$ & 19.6 & 15.7 & 0.002 \\
\hline \multicolumn{5}{|l|}{ C. Work and pesticide use history } \\
\hline $\begin{array}{l}\text { Cumulative time on current job (months), } \\
\text { mean } \pm S D\end{array}$ & $77 \pm 60$ & $68 \pm 80$ & $116 \pm 67 \dagger$ & 0.001 \\
\hline \multirow[t]{2}{*}{ Ever sugarcane work, \% } & $100.0 \dagger$ & 3.6 & 3.8 & $<0.001$ \\
\hline & 24.4 & $5.4 \dagger$ & 21.2 & 0.012 \\
\hline
\end{tabular}


Continued

\section{Sugarcane Construction Farming}

$(\mathrm{N}=86)$

$(\mathrm{N}=56)$

$(\mathrm{N}=52)$

P-value*

Ever plantation (other than

sugarcane), \%

Ever work in small-scale agricultural (\%)

Ever construction work, \%

Ever any pesticide use, \%

61.6†

\section{8}

Glyphosate, \%

2,4-D, \%

$46.5 \dagger$

$25.0 \dagger$

$100.0 \dagger$

$<0.001$

Paraquat, \%

$19.8 \dagger$

$100.0 \dagger$

11.5

$<0.001$

Chlorpyrifos, \%

$23.3 \dagger$

$71.2 \dagger$

$<0.001$

0.0

3.8

$<0.001$

9.3

$0.0 \dagger$

$9.6 \dagger$

$<0.001$

Cypermethrin, \%

0.0

3.6

0.002

$25.0 \dagger$

$<0.001$

Values are mean $\pm S D$ unless indicated otherwise.

* $p$ Value for differences between groups: ANOVA for normally distributed continuous variables,

Kruskal-Wallis for not normally distributed continuous variables, $\chi^{2}$ test for categorical variables.

†Significantly different from the other two categories in post hoc tests.

¥Significant difference only between sugarcane cutters and construction workers.

Open Access This is an Open Access article distributed in accordance with the Creative Commons Attribution Non Commercial (CC BY-NC 4.0) license, which permits others to distribute, remix, adapt, build upon this work noncommercially, and license their derivative works on different terms, provided the original work is properly cited and the use is non-commercial. See: http://creativecommons.org/licenses/by-nc/4.0/

BMJ Open 2017;7:e011034corr1. doi:10.1136/bmjopen-2016-011034corr1

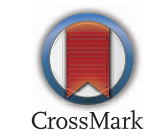

